thirty species of Amazon parrots known; which, then, is "the Amazon parrot" figured? The text is appealed to for an answer in vain. Not two lines are devoted to the Macaws. The same is very much the case all through : thus, the honey-guide is figured after Keuleman's sketch; eleven species are known, but neither is the name given of the species figured, nor is the name given of the species whose habits are described. The common goat-sucker, the whip-poor-will, and the lyre-tailed nightjar, are figured, and yet no scientific names for them are to be found. No doubt both author and editor will agree with us that the value of this work would be greatly added to if the good example set in this matter by Mr. Dallas were followed. The illustrations are in general very good, but is there not one egg too many in the nest of the edible-nest swiftlet? The general get-up of the volume-type, paper, and binding-are all that could be wished, and despite the few things in it which we think might be amended, we most cordially recommend it and its predecessors as very excellent volumes on the natural history of the mammals and birds.

\section{PROF. HUXLEY ON TECHNICAL EDUCATION}

$A \mathrm{~T}$ the lecture by Prof. Silvanus Thompson, on "Apprenticeships," at the Society of Arts last week, Prof. Huxley was in the Chair, and in inviting discussion on the paper, said he would commence it by making a few remarks himself. He had listened to Prof. Thompson's paper with gratification, not only on account of the good sense it embodied, but also for a more selfish reason, inasmuch as it entirely accorded with the views which he, coming to the matter from a different side, had himself expressed. Unfortunately he had no personal acquaintance with the ordinary kinds of work in what were called handicrafts, but he ventured some two years ago in that very room to point his remarks with respect to technical education by the knowledge he possessed of medical education. He then expressed a hope that something real and practical would soon be done by the City Guilds, which had done him the honour of consulting him on this subject of technical education, and the advice he gave them was in precise accordance with the principles which Prof. Thompson had laid down that night. Whatever might be the merits or demerits of the old system of apprenticeship, it was as thoroughly doomed in the different kinds of ordinary handicrafts as it had been long doomed in physic. The only alternatives appeared to him to be of two kinds. In the first place, we ought to bring within the reach of the young people who were employed in our great manufactures the means of carrying on their education in the particular branches of business with which they were respectively occupied beyond the time during which the necessities of practical life obliged them to be at work in the workshop-that is to say, for a period corresponding virtually with what used to be their apprenticeship. One of his suggestions, therefore, was that there should be established in the neighbourhood of the great centres of industry schools to which young boys who are learning certain handicrafts could resort in order to receive instruction which would qualify them to work skilfully and intelligently at their trade. He likewise suggested that the guilds should employ part of their large funds in the establishment of a central institution, which should do for the teaching-power of the country that which such institutions as the École des Arts et Metiers in France, and the Polytechnicum at Zurich, did in their respective countries. In England there was not only a total absence of schools to which apprentices could resort, but there were no teachers competent to teach in such schools, even if they were established. He thought that the suggestions he made to the guilds were of a sound and practical nature, and calculated to advance the interests of technical education in this country. He understood Prof. Thompson to object to the existing elementary training in our Board schools on the ground of its technical nature and of its occupying the minds of the student entirely with book learning and matters which had no sort of bearing on his future life. No one endeavoured more earnestly than he, when he occupied a seat at the School Board, to remedy the evil of the exclusively book character of our ordinary school instruction. He did not entertain the slightest doubt that an extension of the Kindergarten system, including the use of tools and the knowledge of elementary machines, was a matter of great importance, but he could not think that the evil of not giving hand-work in the elementary schools was after all very great. Although it was a great thing to make skilled workmen, yet it was much more important to make intelligent men. The four or five years during which children ordinarily remained at school were not too much to devote to even an exclusive study of reading, writing, and arithmetic, and to the acquirement of some intelligent knowledge of geography, the elements of history, and the rudiments of physical science. On this point he might observe that no pupil was admitted to the Ecoles d'Apprentis in Paris until he was thirteen years old, or unless he presented his certificate of elementary education. If we attained one half or a quarter of the good results reached in the Écoles d'Apprentis, the improvement in the condition of the average British workman would be exceedingly great.

In proposing a vote of thanks to Prof. Thompson for his paper, Prof. Huxley expressed his belief that, as far as London was concerned, it would be a scandal and a robbery if a single shilling were asked for out of the general revenues of the country for technical education. The City of London Guilds possessed enormous wealth, which had been left to them for the benefit of the trades they represent. If the people did not insist on the wealth being applied to its proper purpose, they deserved to be taxed down to their shoes. It would be well if those who had charge of these matters in the city of London would understand that they were morally bound to do this work for the country, and he hoped if they continued to neglect the obligation they would be legally compelled to do it.

\section{NOTES}

No more than justice has been done to Sir Joseph Whitworth by granting him a prolongation for five years for his process of manufacturing fluid-compressed steel. The powerful evidence brought before the Committee of the Privy Council as to the utility of this steel could not be resisted. Mr. James Wright, the Engineer-inChief of the Navy, stated that the invention " has met a want long felt for the principal parts of marine engines which have been subject to failures ;" from his experience of it he has per. fect trust in it. Mr. Hotchkiss, the patentee of the revolving cannon used by the French Government, stated that he never had occasion to reject a single barrel of the steel. The evidence from Mr. J. Davidson, of Woolwich, Mr. Purdey, the wellknown gun-maker, and others, showed that by getting rid of the air-cells the steel answered perfectly, and is a better metal than had ever been produced by any previous process. Their Lordships were satisfied that it would in all probability be highly useful "in carrying out the highest achievements of engineering skill."

THE long-expected experiments by the Thunderer Gun Committee commenced on Tuesday at the proof butts on the Government marshes, Woolwich. In connection with these experiments, Sir William Palliser organised, and last week carried out, a successful series of experiments with a doubly. loaded gun, in order to ascertain whether double-loading was or was not the cause of the bursting of the Thunderer's gun. Five 